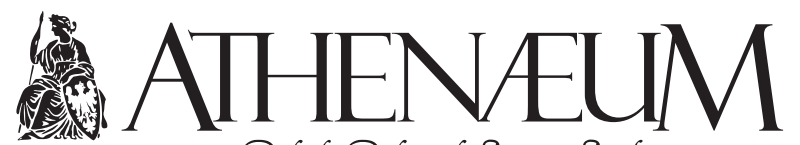

Polish Political Science Studies

Polskie Studia Politologiczne

\title{
BALANCING THE WIN-SETS: AGRICULTURAL LOBBY AND JAPAN'S ACCESSION TO THE TRANS-PACIFIC PARTNERSHIP AGREEMENT*
}

\author{
ROLNICZE LOBBY A AKCESJA JAPONII DO POROZUMIENIA \\ TRANSPACYFICZNEGO
}

Karol Żakowski** (1)

\begin{abstract}
Due to strong connections with the Liberal Democratic Party (LDP) and the Democratic Party of Japan (DPJ), the agricultural lobby constituted a considerable obstacle in liberalization of trade by Japan. Nevertheless, in the last years, its influence on governmental policy has been waning. Referring to the theory of two-level games, the article analyzes the discourse on accession to the Trans-Pacific Partnership (TPP) Agreement to examine the weakening dependence of Japanese politicians on support from the Central Union of Agricultural Cooperatives. It is argued that the Japanese government managed to sign both the TPP Agreement in 2016 and its successor, the Comprehensive and Progressive Agreement for Trans-Pacific Partnership in 2018, thanks to the institutional strength and negotiation strategy of the Abe administration.
\end{abstract}

Ze względu na silne powiązania z Partią Liberalno-Demokratyczną i Partią Demokratyczną lobby rolnicze stanowiło istotną przeszkodę w liberalizacji handlu przez Japonię. Niemniej jednak w ostatnich latach jego wpływ na politykę rządu osłabł. Nawiązując do teorii gier dwupoziomowych (theory of two-level games), w artykule dokonano analizy dyskursu dotyczącego przystąpienia do Partnerstwa Transpacyficznego (TPP) pod kątem słabnącej zależności japońskich polityków od wsparcia ze strony Centralnego Związku Spółdzielni Rolniczych. Stwierdzono, że rządowi Japonii udało się podpisać zarówno umowę o TPP w 2016 roku, jak i jej kontynuację, Kompleksową i progresywną umowę o partnerstwie transpacyficznym w 2018 roku, dzięki sile instytucjonalnej i strategii negocjacyjnej rządu premiera Abe Shinzō.

* This article is a result of research conducted as a part of project "Evolution of the Core Executive under Prime Minister Abe's Government in Japan" financed by the National Science Centre, Poland (DEC-2016/23/B/HS5/00059).

** University of Łódź, Faculty of International and Political Studies. 
Keywords: Trans-Pacific Partnership; Japan; agricultural lobby; liberalization of trade; two-level game theory
Słowa kluczowe: Porozumienie Transpacyficzne; Japonia; lobby rolnicze; liberalizacja handlu; teoria gier dwupoziomowych

\section{INTRODUCTION}

Originally, the TPP was signed as the Trans-Pacific Strategic Economic Partnership Agreement by Brunei, Chile, Singapore, and New Zealand in 2005. The agreement aimed at eliminating all barriers on trade, including differences in intellectual property rights. Gradually, also Australia, Canada, Malaysia, Mexico, Peru, Vietnam, and the US joined the initiative. The Japanese government started planning participation in TPP negotiations in 2010, which immediately became a controversial issue. The main opponent of the agreement, the agricultural lobby, has been known as one of the strongest pressure groups in Japan. Due to the fact that the Liberal Democratic Party (LDP), which ruled over Japan almost unceasingly since 1955, relied on electoral support from farmers, it represented their interests. In addition, many lawmakers from the Democratic Party of Japan (DPJ), that formed government from 2009 to 2012, originated from countryside constituencies. As the Japanese agricultural sector was prevalently based on small farms, its products remained uncompetitive against imported food. As a result, conservative politicians protested any attempts at lowering tariffs on agricultural products. Under these circumstances, it is not surprising that they tried to block Japan's participation in the TPP. While the agricultural lobby largely succeeded under the Kan Naoto (2010-2011) and Noda Yoshihiko (2011-2012) administrations, it failed under the second Abe cabinet (2012-2020).

Referring to the theory of two-level games, this article analyzes the relationship between the erosion of the agricultural lobby's strength and negotiations over accession to the TPP. It is examined how Prime Minister Abe used institutional tools and international pressure to weaken the political influence of farmer unions and push liberalization of trade forward. The DPJ and Abe administrations are compared regarding their institutional efficiency, reliance on support from farmer unions, as well as negotiation strategy. Unlike the DPJ, Abe found a balance between the need to weaken the agricultural lobby domestically and to take advantage of its resistance against the TPP in international negotiations. It is argued that while the DPJ government lacked an effective negotiation strategy and institutional resources to increase the 
win-set, the second Abe cabinet managed to pacify opponents and sign the TPP Agreement thanks to the government's strong position against the bureaucrats and LDP backbenchers.

\section{THEORETICAL AND METHODOLOGICAL APPROACH}

Analysis is based on two-level game theory. As pointed out by Putnam (1988, pp. 435-452), international negotiations of all treaties are conducted on two levels. Level I signifies the official talks between the governments of different countries to achieve a tentative agreement, while Level II refers to discussions within each state to persuade distinct domestic parties, interest groups, and bureaucratic agencies to ratify the agreement. Both levels are interrelated. The larger the set of all possible international deals that would be acceptable for majority of domestic actors (so-called "win-set"), the more probable the ratification becomes. On the other hand, the smaller the perceived win-set of a negotiator, the stronger his/ her international bargaining position. The win-set's size depends on three factors: Level II preferences and coalitions, Level II institutions, as well as Level I negotiators' strategies.

Japan's participation in negotiations on TPP accession attracted a considerable interest from economists and political scientists. It has also not been uncommon to interpret TPP negotiations from the perspective of two-level game theory. As pointed out by Sakuyama (2015), foreign pressure, especially from the US, as well as linkage of liberalization of trade with other issues of concern for policymakers favored joining TPP talks. What hindered negotiations was the strength of domestic veto players. Shinoda (2020), in turn, draws attention to the international factors, such as entry into force of Japan-Australia Economic Partnership Agreement or establishment of the Asian Infrastructure Investment Bank (AIIB) by China that motivated the US to reach a compromise over the TPP with Japan. According to Akimoto (2019), Japan's accession to the TPP can be interpreted both from the perspective of liberalism/neoliberalism, as a method for promotion of free trade and regionalization, and from the realist/neorealist point of view, as pursuance of national economic interests and a way for strengthening alliance with the US. Terada (2019, pp. 1048-1052), in turn, points to the empowerment of Prime Minister Abe and the weakening of agricultural lobby as intervening variables that facilitated TPP negotiations. 
This study supplements the abovementioned findings with an analysis of institutional efficiency and negotiation strategy of the Japanese government in comparative perspective. Instead of examining policy on TPP of a single administration, it comprehensively describes the factors behind TPP negotiations under the DPJ and Abe cabinets. It is argued that while all governments in question were equally exposed to strong pressure from the agricultural lobby, unlike Prime Minister Abe Shinzō, Prime Ministers Kan Naoto and Noda Yoshihiko were unable to establish top-down decision-making rules. What hindered them from stabilizing the institutional setting was frequent change of cabinets and the Great East Japan Earthquake of 2011, which resulted in sudden shifts in policy priorities. It is the success of institutional reforms by the Abe cabinet and the failure thereof by the DPJ administration that explains why the former managed to overcome domestic opposition against the TPP, while the latter could not even start official negotiations on the controversial agreement.

Interestingly, scholars disagree over the impact of TPP on Japanese agriculture. Accession to the agreement has been interpreted either as a far-going concession from Tokyo (Choi \& Oh, 2017, pp. 244-245) or as a lost opportunity to completely open the agricultural market (Honma \& George Mulgan, 2018, p. 133). According to two-level game theory, the negotiation result was a consequence of the size of Japan's win-set as well as the government's political interests. As indicated by Putnam (1988, p. 457), the chief negotiator may aim to shift "the balance of power at Level II in favor of domestic policies that he prefers for exogenous reasons". In this light, Abe's success was twofold. On the international level, Japan managed to join the TPP without the need to abolish all tariffs on trade in the most sensitive agricultural products. On the domestic level, in turn, Abe succeeded in adding agricultural reform to his policy agenda as one of the methods for boosting the economic growth.

Analysis is based on comparative method, which enables tracing dynamic changes in political and institutional determinants of TPP negotiations. In line with the theory of two-level games, this article examines three factors influencing the size of Japan's win-set in TPP talks: (1) the distribution of power, preferences, and possible coalitions among Level II constituents; (2) the Level II political institutions; as well as (3) the strategies of the Level I negotiators. The impact of each determinant on the outcome of TPP accession negotiations is analyzed in two periods: under the DPJ administration (2009-2012) and after regaining power by the LDP in December 2012. 
Comparison between the two periods is conducted through examination of qualitative data acquired from governmental and party documents, academic monographs, journal and newspaper articles, as well as politicians' memoirs. The author also conducted interviews with politicians in the Japanese Diet. Thanks to this broad spectrum of sources, the decision-making process on TPP accession is analyzed not only through strictly legal and institutional lenses, but also through the examination of backstage balancing techniques used by the Abe administration to weaken the solidarity of the agricultural lobby.

Research results are divided into three sections corresponding to the three determinants of the win-set's size formulated by Putnam (1988, pp. 441-452). Each section compares situation under the DPJ and the second Abe administration. It is argued that DPJ leaders were less efficient than Prime Minister Abe in preparing an effective negotiation strategy. In particular, they did not take sufficient advantage of the institutional resources at their disposal to weaken the political strength of the agricultural lobby, thus increasing the win-set in international negotiations.

\section{THE DISTRIBUTION OF POWER, PREFERENCES, AND POSSIBLE COALITIONS AMONG LEVEL II CONSTITUENTS}

Japanese bureaucrats, politicians, interest groups, and the general public were largely polarized over TPP accession. Participation in TPP negotiations was promoted by the Ministry of Economy, Trade and Industry (METI) and the Ministry of Foreign Affairs (MOFA). The former considered liberalization of trade as a necessary measure to help big corporations and boost economic growth, while the latter perceived the new agreement as a way for ensuring maintenance of US-centered international order in the Asia-Pacific, which was instrumental in counterbalancing the rising China. Kōno Tarō, who served as foreign minister from 2017 to 2019, admitted that the TPP was aimed not only at building new rules of trade in the Asia-Pacific, but also at enhancing the regional security system ${ }^{1}$. The main opponent of participation in the agreement, in turn, was the Ministry of Agriculture, Forestry and Fisheries (MAFF), which protected Japan's inefficient agricultural sector. Similar divi-

\footnotetext{
${ }^{1}$ Author's interview with Kōno Tarō, Tokyo, October 20, 2016.
} 
sions were visible among politicians. The members of both major Japanese parties - the LDP and the DPJ - were affiliated to so-called "parliamentary tribes" (zoku giin), informal groups of lawmakers experienced in one legislative field and representing the interests of the corresponding ministry (Yuasa, 1986, pp. 10-16). Agriculture, along with commerce and industry zoku, belonged to the most influential ones (Inoguchi \& Iwai, 1987, p. 133). After the end of Cold War, external pressure for Japan's participation in East Asian regionalization initiatives increased, but the political influence of the agricultural lobby remained intact (Zhang, 2011, pp. 174-176). Under these circumstances, it is not surprising that policy divisions over TPP accession ran across rather than between the two biggest parties.

It is the DPJ that held power when the TPP topic appeared in public sphere. During his general policy speech to the Diet in October 2010, Prime Minister Kan Naoto revealed his intention to "look into participating in such negotiations as those for the Trans-Pacific Partnership agreement" (Kan, 2010). He probably watered down his declaration by using expression "such as" out of consideration for the MAFF (Shimizu, 2011, pp. 217-218). Nevertheless, the prime minister's statement encountered strong opposition among backbenchers of the ruling party. Originally, the DPJ was considered as a party that represented the interests of urban dwellers, but over time it expanded to countryside constituencies. In the 2005 parliamentary election, Prime Minister Koizumi attracted support from unaffiliated voters from big cities, which resulted in DPJ's crushing defeat especially in urban districts. At that time, the percentage of Democrats originating from rural constituencies increased to $60 \%$ (Żakowski, 2015, p. 59). In addition, Ozawa Ichirō, who became DPJ leader in 2006, initiated a so-called "upstream strategy" (kawakami senryaku), aimed at strengthening personal ties between DPJ candidates and voters from agricultural regions. Thanks to this tactics, the Democrats won many seats from countryside districts in the victorious elections to the House of Councilors in 2007 and to the House of Representatives in 2009. When the DPJ ousted the LDP from power and the Hatoyama government was formed in September 2009, in some regions agricultural cooperatives switched their support to the new ruling party or decided to remain neutral (Kawamura, 2011, pp. 33-51). Moreover, a lot of high-ranking DPJ politicians represented provincial prefectures, for instance, Prime Minister Hatoyama Yukio and House of Representatives Speaker Yokomichi Takahiro (Hokkaidō), DPJ Secretary-General Ozawa Ichirō (Iwate Prefecture), former Prime Minister Hata Tsutomu (Nagano Prefecture), and Minister of Foreign Affairs Okada Katsuya 
(Mie Prefecture) (Weiner, 2011, p. 74). Due to this situation, the agricultural lobby boasted strong influence on the DPJ.

The LDP, which regained power in December 2012, was even more dependent on electoral support from farmers. A lot of LDP lawmakers originated from rural regions and maintained strong connections with the National Federation of Agricultural Cooperative Associations (Zennō), along with its political body, the Central Union of Agricultural Cooperatives (JA Zenchū). When the DPJ government started promoting Japan's accession to the TPP in 2010, the agricultural tribe in the LDP insisted that the Liberal Democrats should exclude such possibility. In October 2011, the LDP Research Commission on Comprehensive Agricultural Policy and Trade adopted Resolution against TPP Accession, in which it requested protection of five sensitive agricultural items: rice, beef and pork, dairy products, sugar, and starch (Bochorodycz, 2018a, p. 210). Under this pressure, LDP leader Abe Shinzo promised in the 2012 electoral manifesto that he would never agree on "removal of tariffs without sacred territories" (Liberal Democratic Party, 2002, p. 12). Meanwhile, as many as 240 LDP parliamentarians joined the Association Demanding Prompt Withdrawal from TPP Accession (TPP Sanka no Sokuji Tekkai o Motomeru Kai). After the announcement of Japan's participation in TPP talks by Abe in March 2013, the group changed its name to the Association to Protect National Interest During TPP Negotiations (TPP Kōshō ni Okeru Kokueki o Mamorinuku Kai) and continued to demand maintaining state protectionism towards farmers (Bochorodycz, 2018a, pp. 210-211).

The DPJ and the LDP were internally divided over Japan's accession to the TPP. While the leaders of both parties generally promoted participation in negotiations on liberalization of trade, they encountered strong resistance from the powerful agricultural lobby and lawmakers originating from rural districts. Under these circumstances, prime ministers had to take full advantage of the institutional instruments at their disposal to promote accession to the TPP.

\section{THE LEVEL II POLITICAL INSTITUTIONS}

Constitutional and extra-constitutional decision-making rules determine how difficult it is to ratify an agreement. In Japan, each international treaty has to be passed by a simple majority through both houses of the Diet, but in case of the upper house's veto, the decision of the lower house prevails. As both the 
DPJ in 2009-2012 and the LDP since 2012 enjoyed overwhelming majorities of seats in the House of Representatives (lower house), they could easily ratify the TPP Agreement. The problem was to discipline all party members to vote in line with the cabinet decision and to overcome resistance from the bureaucrats. As a result, an analysis of party and governmental institutions is essential in understanding the determinants of DPJ's failure and LDP's success in TPP negotiations.

The first prime minister from the DPJ, Hatoyama Yukio (2009-2010), tried to conduct ambitious institutional reforms aimed at empowering politicians in the government at the expense of the bureaucrats and DPJ backbenchers. He abolished the Administrative Vice-Ministers' Council and the DPJ Policy Research Committee, two important policymaking venues for the bureaucracy and the ruling party. Inter-ministerial coordination was entrusted to the cabinet committees composed of the ministers related to the respective issues. Such abrupt changes resulted in decision-making disorder (Żakowski, 2015, pp. 64-106). The problem of TPP emerged after US President Barack Obama's visit to Japan in November 2009, when the representatives of the MAFF, METI, MOFA, and the Ministry of Finance started discussing this issue (Bochorodycz, 2018a, p. 207). Nevertheless, Hatoyama did not treat TPP negotiations as a priority, and instead he proposed creation of the East Asian Community together with China and South Korea. He resigned from office in June 2010, due to allegations over illegal donations and criticism over the Futenma issue 2 .

Prime Minister Kan Naoto (2010-2011) tried to repair relations with the bureaucrats and DPJ backbenchers, but his position weakened after upper house election in July 2010. Due to electoral defeat, the DPJ lost majority of seats in the House of Councilors, which complicated decision-making process. Moreover, the agricultural tribe gained in prominence due to reestablishment of the DPJ Policy Research Committee. Kan perceived the TPP not only as a chance to bolster economic growth, but also as a way for improving relations with the US, which had been severed due to the Futenma problem and Hatoyama's concept of the East Asian Community. He wanted to impose TPP accession on the ministries and the ruling party by using the Council on the Realization of a New Growth Strategy

2 US Marine Corps Air Station Futenma, situated in Ginowan in Okinawa, was to be relocated to a different place on the same island. During electoral campaign in 2009, Hatoyama promised he would renegotiate the agreement with the US to move the base at least outside of the prefecture. As he could not persuade the Obama administration to any concession on this matter, he assumed responsibility for breaking the electoral pledge (see: Bochorodycz, 2018b, 137-155). 
(Shin Seichō Senryaku Jitsugen Kaigi) that he had established in September 2010 and directly presided over. The prime minister invited to deliberations of that organ both the experts who shared his views, e.g., Tokyo University Professor Itō Motoshige or Japan Business Federation President Yonekura Hiromasa, and the representatives of farmers led by JA Zenchū President Motegi Mamoru. As Council members became entangled in harsh disputes, they failed to reach any compromise (Shimizu, 2011, pp. 218-221). Eventually, Kan had no choice but to postpone the decision on TPP accession. He stepped down from office in August 2011, taking blame of the organizational disorder during the Fukushima crisis ${ }^{3}$.

Kan's successor, Prime Minister Noda Yoshihiko (2011-2012), was equally powerless in persuading the agricultural lobby to TPP accession. He reestablished permanent meetings of administrative vice-ministers under a changed form and promised he would not make any decision without the DPJ Policy Research Committee's consent. As a result, influence of the bureaucrats on decision-making process increased, and DPJ backbenchers gained a possibility of blocking governmental policies (Żakowski, 2015, pp. 155-175). TPP accession was discussed in the DPJ Policy Research Committee's Economic Cooperation Project Team. The agricultural "parliamentary tribe" was led by Yamada Masahiko who belonged to the Ozawa faction, an intra-party group most critical of Noda. As many as 191 DPJ parliamentarians belonged to the Association Thinking Cautiously about the TPP (TPP o Shinchō ni Kangaeru Kai). Anti-TPP politicians together with the Central Union of Agricultural Cooperatives organized a campaign of gathering signatures under a petition against joining the agreement, which until the end of October 2011 was signed by as many as 356 parliamentarians. Under their pressure, in November 2011, the Project Team issued a final report, in which it urged the government to remain cautious over participation in TPP accession talks (Yomiuri Shinbun Seijibu, 2012, pp. 58-63).

DPJ Policy Research Committee Chairperson Maehara Seiji entrusted the final decision on the TPP to the prime minister. Yamada Masahiko demanded convening the DPJ General Assembly of Parliamentarians from Both Houses and directly hearing the prime minister's explanations. Yamada even threatened he would leave the party unless Noda reconsidered Japan's participation in TPP negotiations (Yomiuri Shinbun Seijibu, 2012, pp. 63-65). In addition, one of DPJ

${ }^{3}$ On March 11,2011, Japan was hit by the Great East Japan Earthquake. The tsunami wave ravaged northeast part of the country and caused radioactive leakage in Fukushima Daiichi Nuclear Power Plant (see: Żakowski, 2015, pp. 140-153). 
lawmakers, Kyōno Kimiko, mentioned a possibility of starting a hunger strike in front of the prime minister's residence (Yamada, 2013, p. 68). At the same time, Minister of Agriculture, Forestry and Fisheries Kano Michihiko revealed his intention to resign from office unless the interests of farmers were protected. As a result, the prime minister assuaged his stance. The final version of the statement on the TPP was written after long discussions between Noda, Kano, and DPJ Secretary-General Koshiishi Azuma. Instead of starting TPP talks, during the Asia-Pacific Economic Cooperation (APEC) summit in Honolulu in November 2011, the prime minister stated he would "enter into consultations with the countries concerned towards participating in the TPP negotiations" (Prime Minister of Japan and His Cabinet, 2011). This ambiguous expression enabled Minister Kano and other opponents of TPP to claim that Japan's participation in accession talks had not yet been decided (Kano, 2013, pp. 194-204).

In December 2012, the LDP ousted the DPJ from power, but the strength of the agricultural lobby remained sound. Just as Kan and Noda, Prime Minister Abe perceived accession to the TPP as a way for accelerating Japan's economic growth. In addition, liberalization of trade became one of the elements of "Abenomics" - Abe's economic strategy that was composed of so-called "three arrows": monetary easing, expansive fiscal policy, and structural reforms to encourage private sector investments (Karube, 2018). To a greater extent than his predecessors, Abe promoted agricultural export as a growth industry. Unlike prime ministers from the DPJ, Abe succeeded in conducting institutional reforms that facilitated him to curb the political influence of MAFF bureaucrats and LDP backbenchers belonging to the agricultural "parliamentary tribe". In 2013, he established a coherent taskforce on the TPP composed of the administrative staff from several ministries, which limited turf battles between them (Choi \& Oh, 2017, p. 242). In 2014, in turn, Abe created the Cabinet Bureau of Personnel Affairs, through which he gained control over appointments of all high-ranking civil servants (Żakowski, 2021, pp. 108-113). As the careers of the bureaucrats now depended on their loyalty towards the prime minister, MAFF employees weakened their opposition against governmental plans. Ruling party backbenchers, in turn, were pacified through circumvention of LDP decision-making organs. By establishing numerous bodies under LDP president's direct control, Abe ensured that the members of the Agriculture and Forestry Policy Division in the LDP Policy Research Council would not block TPP accession.

Aware of the strength of the agricultural zoku, Abe decided to first weaken the solidarity of that group. At the beginning of 2013, the prime minister 
established the LDP Research Council for Regional Diplomatic and Economic Partnership (Gaikō, Keizai Renkei Chōsakai). The organ was placed under Abe's direct jurisdiction and chaired by his trusted associate, Etō Seishirō. Under the Research Council (later Headquarters), in turn, the Committee for TPP Measures (TPP Taisaku Iinkai) was founded. Surprisingly, Abe asked one of the influential members of the agricultural "parliamentary tribe", Nishikawa Kōya, to chair this body. The prime minister probably intended to penetrate the agricultural lobby by buying Nishikawa's loyalty with prestigious posts. As a reward for assuaging LDP backbenchers' resistance against the TPP, in September 2014, Abe appointed Nishikawa as Minister of Agriculture, Forestry and Fisheries (Bochorodycz, 2018a, pp. 211-212). Interestingly, Nishikawa (2017, p. 48) himself admitted in his memoirs that his nomination was a part of Abe's strategy to "control zoku by the use of zoku" (zoku o motte zoku o seisu). Nishikawa closely cooperated with the Government Headquarters for TPP Measures (TPP Seifu Taisaku Honbu), and he engaged Association to Protect National Interest during TPP Negotiations Chairperson Moriyama Hiroshi in the negotiation process as deputy chair of the LDP Committee for TPP Measures. As argued by Nishikawa (2017, pp. 84-393), liberalization of trade would become a positive impetus for Japan's economy, which would cause revival of the agricultural sector. Despite resignation from ministerial post due to a corruption scandal in February 2015, Nishikawa participated in the process of ratification of TPP as the chair of the House of Representatives Special Committee on TPP in 2016.

Another strategy employed by Abe was isolating those members of the agricultural lobby who refused to cooperate from governmental posts. From 2012 to 2014, the office of agriculture minister was entrusted to Hayashi Yoshimasa, who belonged to the financial "parliamentary tribe". Such situation contrasted with the nomination pattern under the DPJ administration, when all agriculture ministers (Akamatsu Hirotaka, Yamada Masahiko, Kano Michihiko, and Gunji Akira) represented the interests of farmers' trade unions. As admitted by Hayashi, while it took a lot of time to force the members of agricultural zoku to cooperate, due to the institutional strength of the Abe cabinet, they had no choice but to comply with governmental policy ${ }^{4}$. Moreover, Abe took advantage of the popularity of young, reform-minded politicians. In particular, LDP Policy Research Council Agriculture and Forestry Policy Division Chair Koizumi Shinjirō proved instrumental in calming the anxiety among farmers. The highly

\footnotetext{
4 Author's interview with Hayashi Yoshimasa, Tokyo, October 16, 2019.
} 
popular son of Prime Minister Koizumi Jun'ichirō participated in 15 meetings in seven prefectures, during which he explained the contents and gravity of the agreement (Bochorodycz, 2018a, pp. 212-213).

Not to let different ministries involved in TPP talks compete each other, Abe designated Minister of State for Economic and Fiscal Policy Amari Akira as responsible for coordination of negotiations (Solís \& Urata, 2018, p. 110). In addition, the prime minister took advantage of bureaucratic appointments to weaken MAFF's connections with the Central Union of Agricultural Cooperatives. For example, Okuhara Masaaki, a reform-minded MAFF bureaucrat, was nominated as agriculture administrative vice-minister in 2016 (George Mulgan, 2018, pp. 46-48). At the same time, the government saturated the MAFF with civil servants from the METI who supported TPP accession. Vice-Minister (and later Minister) of Agriculture, Forestry and Fisheries Saitō Ken, who himself originated from METI, promoted several METI employees to the post of Food Industry Affairs Bureau directors-general. Such a nomination pattern helped the government to overcome the MAFF's opposition against agricultural reform and Japan's accession to the TPP (Taniguchi, 2018, p. 165).

The efficiency of political institutions under the DPJ and LDP administrations differed considerably. After a complete separation of the bureaucrats and DPJ backbenchers from decision-making process under the Hatoyama cabinet, Prime Ministers Kan Naoto and Noda Yoshihiko tried to find a balance between topdown leadership and the necessity for conducting policy coordination with the ruling party and between the ministries. Nevertheless, the institutional instability caused by frequent changes of the heads of government facilitated the agricultural lobby to block Japan's participation in TPP negotiations. By contrast, Prime Minister Abe remained in power long enough to create favorable institutional conditions for liberalization of trade. The newly established Cabinet Bureau of Personnel Affairs enabled him to penetrate the MAFF with METI bureaucrats, while the LDP Research Council for Regional Diplomatic and Economic Partnership proved instrumental in bypassing policymaking organs that remained under control of the agriculture "parliamentary tribe". As a result, it was Abe, not DPJ leaders, who gained the possibility of launching official negotiations on TPP accession. 


\section{THE STRATEGIES OF THE LEVEL I NEGOTIATORS}

In line with two-level game theory, the Japanese government tried to improve its negotiating position at Level I by referring to domestic resistance against the TPP, while using external pressure as an argument for liberalization of trade at Level II. On the one hand, Abe perceived the TPP as a method for promoting Japanese products abroad and a crucial element of the strategy of containing rising China. On the other hand, he referred to the necessity for adapting to globalization processes to justify the need for the reform of the domestic agricultural sector.

Internationally, the biggest line of discontent ran between the US and Japan. While Washington wanted to protect its automobile industry against Japanese cars, Tokyo insisted on partial maintenance of tariffs on agricultural products. As the aim of the agreement was to eliminate all tariffs on trade, even a partial protection of several agricultural items seemed a daring task. Under the DPJ government, Japan could not even respond to US invitation to TPP accession talks. During a meeting with President Obama in French Deauville in May 2011, Prime Minister Kan repeated his intention to make a prompt decision on the TPP, while explaining that delay was caused by the Great East Japan Earthquake (Obama, 2011). Nevertheless, further progress in this field was not achieved until the DPJ was ousted from power by the LDP. It was Prime Minister Abe who managed to gain first concession from the American side during his visit to the US in February 2013. As President Obama stated he would not force Japan to eliminate all tariffs with no exceptions, the head of Japanese government agreed to participate in the negotiations (Akimoto, 2019, p. 3). Nevertheless, elaboration of the details of the US-Japanese deal necessitated three more years of bilateral bargaining.

In August 2013, during the $19^{\text {th }}$ TPP negotiation round in Brunei, Minister of State for Economic and Fiscal Policy Amari Akira stressed that all sides "needed to proceed with the negotiations in a manner that adequately recognized that - just as Japan could not eliminate all tariffs on agricultural goods - it would be difficult for some countries to immediately take on the same rules as those of developed countries" (Amari, 2016, p. 15). Tokyo consistently claimed that due to resistance from farmers, it was unable to simply end protectionist policy towards the agricultural sector. In exchange for other sides' concession on this matter, Japan was ready to display flexibility regarding sensitive products and services in other countries. Amari (2016, p. 15) seemed content that the statement issued after the Brunei meeting added the adjective "balanced" to the previously defined goal of attaining "ambitious", "comprehensive", and "high" level of liberalization. 
As emphasized by him, this expression could be interpreted as "a balance between pursuing ambitious progress and showing concern for the different participants' sensitivities", which conformed with the Japanese demands.

Paradoxically, while using opposition from farmers as an argument in TPP negotiations, Abe took advantage of the plans for liberalization of trade to enforce a revolutionary agricultural reform in Japan. He thus maintained balance between presenting his win-set's size as small to other negotiators and ensuring ratification of the agreement through elimination of farmers' trade unions' political influence. When announcing Japan's participation in TPP negotiations in March 2013, Abe presented his decision not only as an opportunity, but also as a necessity. He said: "It looks as if our country has become inward-looking before we knew it. In the meantime, other countries in the world have dynamically changed their direction towards open economies aiming to incorporate overseas growth. [...] If Japan alone should become inward-looking, we would have no chance of growth. Companies would not invest in Japan then. Talent would not be attracted either. The TPP is a framework which promises 'prosperity in the future' in the Asia-Pacific" (Prime Minister of Japan and His Cabinet, 2013). Regarding the farming sector, Abe lamented the fact that primary farming population was aging rapidly and agriculture was unattractive for young people. For that reason, he called the TPP "not a crisis", but rather "a big chance" for increasing competitiveness, expanding exports, and turning agriculture into a growing industry (Prime Minister of Japan and His Cabinet, 2013).

The necessity for liberalizing trade exchange was used by Abe as an argument for undermining the political influence of farmers' trade unions. During the World Economic Forum in Davos in January 2014, the Japanese prime minister stressed he was "willing to act like a drill bit; strong enough to break through the solid rock of vested interests" (Prime Minister of Japan and His Cabinet, 2014). In particular, he planned abolition of so-called gentan system of subsidies for the farmers who reduced the acreage of rice paddies, which had been aimed at maintaining high rice prices since the 1970s. The reform was supposed not only to make the Japanese agricultural sector more competitive, but also to weaken the political influence of JA Zenchū as a result of the expected discontinuation of farming by small-scale and part-time rice farmers (Terada, 2016, pp. 95-97). Nevertheless, the government did not rush implementation of the reform, and the gentan system was not abolished until 2018 (Nomura, 2018). As a result, the Central Union of Agricultural Cooperatives was not deprived of the funds 
necessary to continue anti-TPP campaign until the end of the negotiation process. Massive rallies of farmers, in turn, lent credibility to Japanese negotiators who claimed Japan would not be able to join the TPP unless its five sensitive agricultural items were protected.

International factors were of importance as well. In particular, China's rising position in the Asia-Pacific prompted the US to draw Japan away from the initiatives competitive to the TPP. It was not a coincidence that President Obama allowed Japan to participate in accession talks only three months after the launch of negotiations on the Regional Comprehensive Economic Partnership (RCEP) by ASEAN countries with China, Japan, South Korea, Australia, and New Zealand in November 2012. Beijing's growing ambition to shape the regional order, exemplified by the foundation of the AIIB in 2015, further motivated Washington to achieve a compromise with Tokyo (Shinoda, 2020).

TPP talks concluded at the meeting in Atlanta in October 2015. As displayed in Table 1, while an average tariff elimination rate was $99.95 \%$, for Japan it remained at $95 \%$, the lowest of all member states. In particular, Japan committed to eliminating only $51.3 \%$ of tariffs on agricultural products at the initial stage of implementation of the agreement, and $81 \%$ after the transitory period of up to 12 years. As an average commitment in this field amounted to $81.72 \%$ and $97.07 \%$, respectively, Tokyo managed to negotiate a relatively good deal. The TPP was eventually signed by the representatives of 12 countries on February 4, 2016, in Auckland, New Zealand. Nevertheless, realization of the agreement was put into question after US withdrawal from the initiative by President Donald Trump in January 2017. Japan became a leading force behind negotiations of the new version of TPP without US participation. The Comprehensive and Progressive Agreement for Trans-Pacific Partnership, dubbed by Prime Minister Abe "Ocean's Eleven", was signed in March 2018 in Santiago de Chile by representatives of 11 countries and ratified by Japan in July 2018. The provisions concerning the US were suspended, so as to enable US participation in the future (Żakowski, 2019, pp. 93-94).

While the DPJ government's international bargaining on the TPP did not exceed preliminary plans of a potential participation in accession talks, the Abe administration conducted time-consuming, yet successful, negotiations with the US and other sides of the agreement. On the one hand, thanks to massive anti-TPP protests by farmers, Japanese negotiators managed to maintain their perceived win-set small. On the other hand, Abe referred to the necessity for liberalization of trade as an argument for eliminating the political influence of the 
Table 1. Committed Tariff Elimination Rates under the TPP

\begin{tabular}{|l|c|c|c|c|c|}
\hline \multirow{2}{*}{} & \multicolumn{2}{|c|}{ Agricultural products } & \multicolumn{2}{c|}{ Manufactured goods } & \multirow{2}{*}{ Total } \\
\cline { 2 - 5 } & Immediately & Eventually & Immediately & Eventually & \\
\hline Japan & $51.3 \%$ & $81 \%$ & $95.3 \%$ & $100 \%$ & $95 \%$ \\
\hline USA & $55.5 \%$ & $98.8 \%$ & $90.9 \%$ & $100 \%$ & $100 \%$ \\
\hline Australia & $99.5 \%$ & $100 \%$ & $91.8 \%$ & $99.8 \%$ & $100 \%$ \\
\hline Brunei & $98.6 \%$ & $100 \%$ & $90.6 \%$ & $100 \%$ & $100 \%$ \\
\hline Canada & $86.2 \%$ & $94.1 \%$ & $96.9 \%$ & $100 \%$ & $99 \%$ \\
\hline Malaysia & $96.3 \%$ & $99.5 \%$ & $94.7 \%$ & $100 \%$ & $100 \%$ \\
\hline Mexico & $74.1 \%$ & $96.4 \%$ & $77 \%$ & $99.6 \%$ & $100 \%$ \\
\hline New Zealand & $97.7 \%$ & $100 \%$ & $93.9 \%$ & $100 \%$ & $100 \%$ \\
\hline Peru & $82.1 \%$ & $96 \%$ & $80.2 \%$ & $100 \%$ & $99 \%$ \\
\hline Singapore & $100 \%$ & $100 \%$ & $100 \%$ & $100 \%$ & $100 \%$ \\
\hline Vietnam & $42.6 \%$ & $99.4 \%$ & $70.2 \%$ & $100 \%$ & $100 \%$ \\
\hline Average & $81.72 \%$ & $97.07 \%$ & $88.36 \%$ & $99.65 \%$ & $99.95 \%$ \\
\hline
\end{tabular}

Source: Compiled by the author, based on data from Cabinet Secretariat (2015).

Central Union of Agricultural Cooperatives, which, however, he accomplished only after ratification of the TPP. Such negotiating strategy enabled Japan to maintain a lower liberalization rate than other TPP members states.

\section{CONCLUSIONS}

Japan's participation in TPP negotiations can be interpreted as a two-level game conducted at the international and domestic levels. What explains the Abe cabinet's success and the DPJ administration's failure in the talks was mainly the former government's institutional strength and the latter's organizational weakness. Prime Ministers Kan Naoto and Noda Yoshihiko seemed as determined to start TPP negotiations as Abe Shinzō, but they lacked institutional instruments necessary to overcome the resistance from the agricultural lobby. Frequent changes of prime ministers, each having his own vision of decisionmaking process, weakened the DPJ leaders' position vis-à-vis the bureaucrats and ruling party backbenchers. Gradual institutional reforms implemented by Abe, in turn, facilitated him to impose his will on the agricultural lobby in 
a top-down manner. The Cabinet Bureau of Personnel Affairs enabled penetration of the MAFF with METI bureaucrats, and the LDP Research Council for Regional Diplomatic and Economic Partnership proved instrumental in circumventing policymaking organs that remained under control of the LDP agriculture $z o k u$.

In line with the two-level game theory, the chief negotiator took advantage of the complex interaction between domestic and international factors behind liberalization of trade. The institutional efficiency facilitated him to appeal for TPP accession by referring to external determinants, such as the necessity to adapt to globalization processes and contain the rising China. While undermining the political influence of the agricultural lobby at the domestic level, the Abe cabinet cited resistance from farmers as an argument for maintaining tariffs on five sensitive agricultural items in international negotiations. This time-consuming, yet effective, negotiating strategy resulted in partial protection of farmers' interests without blockage of TPP talks by the agricultural lobby.

\section{REFERENCES:}

Akimoto, D. (2019). Japan's Policy on the Trans-Pacific Partnership (TPP) in Light of IR Theory and Analytical Eclecticism. Journal of International and Global Studies, 10(2), 1-20.

Amari, A. (2016). The Trans-Pacific Partnership (TPP) Agreement. Asia-Pacific Review, 23(1), 11-20. DOI: 10.1080/13439006.2016.1195948.

Bochorodycz, B. (2018a). Abe Cabinet and the TPP Negotiations on "Trade Sensitivities". In: K. Żakowski, B. Bochorodycz, \& M. Socha, Japan's Foreign Policy Making: Central Government Reforms, Decision-Making Processes, and Diplomacy (pp. 203-231). Cham: Springer.

Bochorodycz, B. (2018b). The Issue of Futenma Under the Koizumi and Hatoyama Cabinets. In: K. Żakowski, B. Bochorodycz, \& M. Socha, Japan's Foreign Policy Making: Central Government Reforms, Decision-Making Processes, and Diplomacy (pp. 137-155). Cham: Springer.

Cabinet Secretariat (2015, October 20). TPP ni okeru Kanzei Kōshō no Kekka [Result of Negotiations on Tariffs in the TPP]. Retrieved December 29, 2020 from: https:// www.cas.go.jp/jp/tpp/tppinfo/2015/pdf/151020_tpp_kanzeikousyoukekka.pdf.

Choi, B., \& Oh, J.S. (2017). Reversed Asymmetry in Japan's and Korea's FTAs: TPP and Beyond. Pacific Focus, 32(2), 232-258. DOI: 10.1111/pafo.12091.

George Mulgan, A. (2018). The Abe Administration and the Rise of the Prime Ministerial Executive. London and New York: Routledge. 
Honma, M., \& George Mulgan, A. (2018). Political Economy of Agricultural Reform in Japan under Abe's Administration. Asian Economic Policy Review, 13(1), 128-144. DOI: 10.1111/aepr.12208.

Inoguchi, T., \& Iwai, T. (1987). "Zoku Giin" no Kenkyū [A Study on "Parliamentary Tribes"]. Tokyo: Nihon Keizai Shinbunsha.

Kan, N. (2010, October 1). Policy Speech by Prime Minister Naoto Kan at the $176^{\text {th }}$ Extraordinary Session of the Diet. Retrieved October 27, 2020 from: http://japan. kantei.go.jp/kan/statement/201010/01syosin_e.html.

Kano, M. (2013). Nōringyo Fukken no Tatakai: Ichinen Kyūkagetsu no Kiseki [Struggle for the Rehabilitation of Agriculture, Forestry and Fisheries: One Year and Nine Months Path]. Tokyo: Zaikaikenkyūjo.

Karube, K. (2018). Kanryōtachi no Abenomikusu. Ikei no Keizai Seisaku ha Ika ni Tukuraretaka [Abenomics of the Bureaucrats: How Was the Odd-looking Economic Policy Created]. Tokyo: Iwanami Shoten.

Kawamura, K. (2011). Rieki Dantai no Dōtai to Seiken Kōtai - Nōgyōhyō no Yūkai [Change of Government and the Interest Group: Meltdown of the Agricultural Organized Votes]. Nenpō Seijigaku, 2, 33-51.

Liberal Democratic Party (2012). Nihon o Torimodosu [Restore Japan]. Retrived October 3, 2020 from: https://jimin.jp-east-2.storage.api.nifcloud.com/pdf/seisaku_ ichiban24.pdf?_ga=2.156227707.1712537556.1554297229-464335118.1554297229.

Nishikawa, K. (2017). TPP no Shinjitsu: Sōdaina Kyōtei o Matomeageta Otokotachi [Truth About the TPP: The Men Who Finalized the Grand Agreement]. Tokyo: Kaitakusha.

Nomura, H. (2018, October 19). End of 'Gentan' - Will the End of Regulated Reduction of Cultivated Land Result in the Increase or Decrease of Future Rice Supply in Japan? FFTC Agricultural Policy Platform. Retrieved November 21, 2020 from: https://ap.fftc.org.tw/article/1329.

Obama, B. (2011, May 26). Remarks Following a Meeting with Prime Minister Naoto Kan of Japan in Deauville, France. Retrieved March 25, 2020 from: https://www. presidency.ucsb.edu/documents/remarks-following-meeting-with-prime-ministernaoto-kan-japan-deauville-france.

Prime Minister of Japan and His Cabinet (2011, November 13). Press Conference by Prime Minister Yoshihiko Noda on the Occasion of the $19^{\text {th }}$ APEC Economic Leaders' Meeting. Retrieved November 27, 2020 from: http://japan.kantei.go.jp/noda/ statement/201111/13naigai_e.html.

Prime Minister of Japan and His Cabinet (2013, March 15). Press Conference by Prime Minister Shinzo Abe. Retrieved December 26, 2020 from: https://japan.kantei. go.jp/96_abe/statement/201303/15kaiken_e.html.

Prime Minister of Japan and His Cabinet (2014, January 22). A New Vision from a New Japan, World Economic Forum 2014 Annual Meeting, Speech by Prime Minister Abe. Retrieved December 15, 2020 from: https://japan.kantei.go.jp/96_abe/ statement/201401/22speech_e.html. 
Putnam, R.D. (1988). Diplomacy and Domestic Politics: The Logic of Two-Level Games. International Organization, 42(3), 427-460. DOI: 10.1017/S0020818300027697.

Sakuyama, T. (2015). Nihon no TPP Kōshō Sanka no Shinjitsu: Sono Seisaku Katei no Kaimei [The Truth of Japan's Participation in the TPP Negotiations: Revealing Its Policy Process]. Tokyo: Bunshindō.

Shimizu, M. (2011). Seiken Kōtai no 600 Nichi [600 Days of Alternation of Power]. In: T. Sasaki, \& M. Shimizu (Eds.). Zemināru Gendai Nihon Seiji [Seminar on the Present Japanese Politics] (pp. 1-222). Tokyo: Nihon Keizai Shinbun Shuppan.

Shinoda, T. (2020). Two-Level Game Analysis of Japan in the TPP Negotiations. Asian Journal of Comparative Politics, 5(4), 337-350. DOI: 10.1177/2057891119865025.

Solís, M., \& Urata, S. (2018). Abenomics and Japan's Trade Policy in a New Era. Asian Economic Policy Review, 13(1), 106-123. DOI: 10.1111/aepr.12205.

Taniguchi, T. (2018). Abe Shinzō no Shinjitsu [Truth About Abe Shinzō]. Tokyo: Gokū Shuppan.

Terada, T. (2016). Japan and Entanglement of Regional Integration in the Asia-Pacific: Combining Cutting-Edge and Traditional Agendas. In: S. Basu Das, \& M. Kawai (Eds.). Trade Regionalism in the Asia-Pacific: Developments and Future Challenges (pp. 85-101). Singapore: ISEAS - Yusof Ishak Institute.

Terada, T. (2019). Japan and TPP/TPP-11: Opening Black Box of Domestic Political Alignment for Proactive Economic Diplomacy in Face of 'Trump Shock'. The Pacific Review, 32(6), 1041-1069. DOI: 10.1080/09512748.2019.1617771.

Weiner, R.J. (2011). The Evolution of the DPJ: Two Steps Forward, One Step Back. In: L.J. Schoppa (Ed.). The Evolution of Japan's Party System: Politics and Policy in an Era of Institutional Change (pp. 63-98). Toronto-Buffalo-London: University of Toronto Press.

Yamada, M. (2013). TPP Himitsu Kōshō no Shōtai [Truth about TPP Secret Negotiations]. Tokyo: Takeshobō.

Yomiuri Shinbun Seijibu (2012). Minshu Gakai. Seikai Daikonmei eno 300 Nichi [Collapse of the DPJ: 300 Days towards a Great Confusion of the Political World]. Tokyo: Shinchōsha.

Yuasa, H. (1986). Kokkai "Giin Zoku”- Jimintō "Seichō” to Kasumigaseki ["Parliamentary Tribes" - Kasumigaseki and the LDP "PARC”]. Tokyo: Kyōikusha.

Zhang, Y. (2011). Riben de Nongye Baohu yu Dongya Diquzhuyi [Japan's Agricultural Protection and East Asian Regionalism]. Tianjin: Tianjin Renmin Chubanshe.

Żakowski, K. (2015). Decision-Making Reform in Japan: The DPJ's Failed Attempt at a Politician-Led Government. London-New York: Routledge.

Żakowski, K. (2019). Revision of Japan's Foreign Policy After Donald Trump's Electoral Victory. International Studies: Interdisciplinary Political and Cultural Journal, 23(1), 85-101. DOI: 10.18778/1641-4233.23.06.

Żakowski, K. (2021). Gradual Institutional Change in Japan: Kantei Leadership under the Abe Administration. London-New York: Routledge. 